\title{
Evaluation of the quality of pet foods using fast techniques and official methods
}

\author{
Avaliação da qualidade de rações utilizando métodos rápidos e métodos oficiais
}

\author{
Cibele Cristina OSAWA ${ }^{1 *}$, Lireny Aparecida Guaraldo GONÇALVES ${ }^{1}$, Sidnei RAGAZZI ${ }^{2}$
}

\begin{abstract}
This paper was designed to evaluate the rancidity of 18 pet food samples using the Diamed FATS kits and official AOCS methods for the quantification of free fatty acids, peroxide value and concentrations of malonaldehyde and alkenal in the lipid extracted. Although expiration dates have passed, the samples presented good quality evidencing little oxidative rancidity. The results of this study suggest that the Brazilian pet food market is replete with products of excellent quality due to the competitiveness of this market sector.

Keywords: pet foods; lipid oxidation; quality; correlation; AOCS methods; kits.
\end{abstract}

\section{Resumo}

O presente trabalho teve como objetivo avaliar 18 amostras de rações, utilizando kits Diamed FATS e métodos oficiais da AOCS para quantificações de ácidos graxos livres, índice de peróxido e concentrações de malonaldeído e alquenais no lipídio extraído. Embora estivessem fora do prazo de validade, as amostras apresentaram boa qualidade, indicada pelos baixos valores de rancidez oxidativa. Os resultados deste estudo sugerem que o mercado brasileiro de rações conta com produtos de excelente qualidade, devido à competitividade do setor.

Palavras-chave: rações; oxidação lipídica; qualidade; correlação; métodos da AOCS; métodos rápidos.

\section{Introduction}

The pet food market in Brazil has been growing rapidly. Reports show a growth average of $20 \%$ per year during the 1990 s and an accumulated increase of more than 400\% from 1994 to 2001 (MESQUITA, 2004). According to the Brazilian pet food manufacturers association (Associação Nacional dos Fabricantes de Alimentos para Animais - ANFAL), the Brazilian pet food market has a potential of more than 3.2 million tons to feed 38 million pets including 27 million dogs and 11 million cats (ALIMENTOS PARA BICHOS DE ESTIMAÇÃO, 2004).

The potential for continuos growth is high since only $40 \%$ of all pets are fed on industrialized products (CUTAIT, 2004). The highly competitive nature of the market means that the quality of the final product, especially the presence of rancidity resulting from lipid oxidation, can have a critical impact on sales and should be monitored.

The oil and fat components of the formula are responsible for the main sensory alterations that occur in pet foods during their shelf lives due to lipid oxidation, also known as rancidity. Rancidity has a great economic impact on the food industry because it leads to undesirable flavors and odors. Moreover, it can diminish the nutritional quality of foods and produce toxic products (NAWAR, 1996). Since the acceptance of foods containing lipids in their constitution depends on the extent of their oxidation (GRAY, 1978), monitoring lipid oxidation is crucial to determine the quality of pet foods.
Rancidity can be divided into hydrolytic rancidity and oxidative rancidity. Hydrolytic rancidity is the hydrolysis of an ester bond by lipase or moisture. It refers to fats and oil hydrolysis producing free fatty acids (FFA) by the action of enzymes present in the oilseed grains or of microbiological origin. Also, hydrolytic rancidity may occur non-enzymatically at high temperatures producing FFA (HUI, 1996).

Oxidative rancidity is very complex and involves a considerable number of reactions. The oxidation rate is affected by the fatty acid composition of the foods, degree of unsaturation of the fats, presence and activity of pro-oxidants and antioxidants, partial pressure of the oxygen and storage conditions of the foods, such as temperature, and exposure to light and humidity (BELITZ; GROSCH, 1999).

It is mediated by atmospheric oxygen and an unsaturated fat leading to the formation of initial products denominated hydroperoxides and final products such as aldehydes, polymers, glycerides, diglycerides, fatty acids, and etc. (LEA, 1962).

Analytical determinations, such as for free fatty acids (FFA), peroxide values (PV), p-anisidine values (AV), and TBA numbers are used to monitor lipid oxidation. Since many of the pet food manufacturers probably do not have a laboratory equipped for conventional routine analyses, it is very convenient to use fast methods.

\footnotetext{
Recebido para publicação em 15/6/2007

Aceito para publicação em 20/3/2008 (002588)

${ }^{1}$ Laboratório de Óleos e Gorduras, Departamento de Tecnologia de Alimentos, Faculdade de Engenharia de Alimentos, Universidade Estadual de Campinas - UNICAMP,

CEP 13083-862, CP 6121, Campinas - SP, Brasil, E-mail: cibele_osawa@yahoo.com.br

${ }^{2}$ Departamento de Estatística, Universidade Estadual de Campinas - UNICAMP, CEP 13083-970, CP 6065, Campinas - SP, Brasil

${ }^{*}$ A quem a correspondência deve ser enviada
} 
The FFA percentage is the percentage in weight of a specific fatty acid, for example oleic acid, based on the titration with a standard solution of $\mathrm{NaOH}$ using phenolphthalein as the indicator (AOCS, 2004; HUI, 1996). FFA production is the result of hydrolytic rancidity, which occurs enzymatically or otherwise and/or in the presence of moisture and heating (GÓMEZ-PIÑOL; BORONAT, 1989; HUI, 1996).

Peroxides are the main initial products of lipid oxidation and can be measured by iodometric methods (AOCS, 2004), techniques based on iron oxidation (SAFETY ASSOCIATES, 1998; 1999; 2003; 2004), enzymatic reactions, or by physical or chromatographic methods (DOBARGANES; VELASCO, 2002).

The peroxide contents present in the oxidized lipid from animal or vegetable sources are transitory components that decompose into a variety of carbonylic and other compounds, mainly 2,4 dienals and 2-alkenals, in the presence of $\mathrm{p}$-anisidine in an acidic medium. The anisidine value is defined as 100-times the optical density of a solution containing $1.0 \mathrm{~g}$ of fat in $100 \mathrm{~mL}$ of a mixture of solvent and reagent measured at $350 \mathrm{~nm}$ in a $1 \mathrm{~cm}$ cuvette using a spectrophotometer (AOCS, 2004).

The TBA number is calculated as milligrams of malonaldehyde per kilogram of sample. Malonaldehyde is a secondary product of lipid oxidation and can be quantified colorimetrically in the presence of 2-thiobarbituric acid (AOCS, 2004; HAMILTON; ROSELL, 1986). There is a vast literature on TBA test methods. The difficulties, advantages, and drawbacks of each one were described by Osawa, Gonçalves, and Felicio (2005).

The DiaMed Food Analysis Test System (FATS) kits (SAFETY ASSOCIATES, 1998) were designed to substitute the official methods of determining \% FFA, PV, AV and TBA values with fast, easy procedures, employing less toxic reagents, and compact equipment that can be adapted to small areas. They require small quantities of sample generating 4-19 times less residues for treatment than the official methods and provide better work conditions for the analyst involved (OSAWA, 2005; OSAWA; GONÇALVES, 2006b).

They are named FaSafe ${ }^{\mathrm{TM}}$ or AciSafe ${ }^{\mathrm{TM}}$, PeroxySafe $^{\mathrm{TM}}$, AlkalSafe $^{\mathrm{TM}}$, and AldeSafe ${ }^{\mathrm{TM}}$ respectively for the determinations of $\%$ FFA, PV, AV, and TBA number. The results are expressed as $\%$ oleic acid, meq $\mathrm{O}_{2} / \mathrm{kg}$, and nmol.kg ${ }^{-1}$ or $\mu \mathrm{mol} . \mathrm{mL}^{-1}$ for $\% \mathrm{FFA}$, PV, and AV or TBA, respectively (OSAWA, 2005; OSAWA; GONÇALVES, 2006b). According to the sensibility (Table 1) and application (Table 2), they were divided into 3 ranges: HSY, STD, and MSA, which stand for high sensitivity, standard sensitivity, and matrix special applications, respectively.

The \% FFA kit is based on the alteration of $\mathrm{pH}$ using xylenol-orange as the indicator while the quantification with the PeroxySafe ${ }^{\mathrm{TM}}$ kit is based on the oxidation of the ferrous ion in the presence of xylenol-orange in an acidic medium. AldeSafe $^{\mathrm{TM}}$ and AlkalSafe ${ }^{\mathrm{TM}}$ measure the contents of malondialdehyde (TBA) and alkenals (AV) by the quantification of the colored complex formed between malondialdehyde or alkenals and indole.

The PeroxySafe ${ }^{\mathrm{TM}}$ and FaSafe ${ }^{\mathrm{TM}}$ kits have been recognized recently by the AOAC as reliable methods (GORDON, 2004)
Table 1. Detection ranges of the Diamed F.A.T.S. kits.

\begin{tabular}{|c|c|c|}
\hline Analysis & Kit & Detection range \\
\hline \multirow[t]{3}{*}{$\%$ FFA } & FaSafe $^{\text {TM }}$ STD & 0.2 to $2.2 \%$ oleic acid \\
\hline & $\mathrm{FaSafe}^{\mathrm{TM}} \mathrm{HSY}$ & 0.02 to $0.2 \%$ oleic acid \\
\hline & AciSafe $^{\mathrm{TM}}$ MSA & 0.2 to $2.2 \%$ oleic acid \\
\hline \multirow[t]{3}{*}{ PV } & PeroxySafe $^{\mathrm{TM}}$ STD & 0.01 to $0.55 \mathrm{meq} \mathrm{O}_{2} / \mathrm{kg}$ \\
\hline & PeroxySafe $^{\mathrm{TM}}$ HSY & 0.01 to $0.22 \mathrm{meq} \mathrm{O}_{2} / \mathrm{kg}$ \\
\hline & PeroxySafe $^{\mathrm{TM}}$ MSA & 0.01 to $0.22 \mathrm{meq}_{2} / \mathrm{kg}$ \\
\hline \multirow[t]{2}{*}{ TBA } & AldeSafe $^{\mathrm{TM}}$ STD & 0 to $55 \mathrm{nmol} / \mathrm{mL}$ \\
\hline & AldeSafe ${ }^{\mathrm{TM}}$ MSA & 0 to $11 \mathrm{nmol} / \mathrm{mL}$ \\
\hline \multirow[t]{2}{*}{ p-anisidine } & AlkalSafe ${ }^{\mathrm{TM}}$ STD & 7 to $77 \mu \mathrm{mol} / \mathrm{mL}$ \\
\hline & AlkalSafe ${ }^{\mathrm{TM}} \mathrm{MSA}$ & 7 to $77 \mu \mathrm{mol} / \mathrm{kg}$ \\
\hline
\end{tabular}

Table 2. Recommendations for the use of the Diamed F.A.T.S. kits according to the product being analyzed.

\begin{tabular}{|c|c|c|c|}
\hline Analysis & Refined oils & $\begin{array}{l}\text { Pressed oils, } \\
\text { frying fats and } \\
\text { simple matrices }\end{array}$ & Complex matrices \\
\hline$\%$ FFA & $\mathrm{FaSafe}^{\mathrm{TM}} \mathrm{HSY}$ & $\mathrm{FaSafe}^{\mathrm{TM}}$ STD & AciSafe $^{\mathrm{TM}}$ MSA \\
\hline PV & PeroxySafe $^{\mathrm{TM}}$ HSY & PeroxySafe $^{\mathrm{TM}}$ STD & PeroxySafe $^{\mathrm{TM}}$ MSA \\
\hline TBA & AldeSafe ${ }^{\mathrm{TM}}$ STD & AldeSafe $^{\mathrm{TM}}$ STD & AldeSafe $^{\mathrm{TM}}$ MSA \\
\hline $\mathrm{p}$-anisidine & AlkalSafe ${ }^{\mathrm{TM}}$ STD & AlkalSafe ${ }^{\mathrm{TM}}$ STD & AlkalSafe ${ }^{\mathrm{TM}}$ MSA \\
\hline
\end{tabular}

Source: Osawa and Gonçalves (2006b)

and have been certificated by the documents numbered 030405 (SAFTEST, 2003a), and 030501 (SAFTEST, 2003b), respectively.

The kits have been used to evaluate the quality of frying oils and snacks with or without antioxidants (GORDON, 2000b; 2002; GORDON et al., 2000); refined oils (GORDON, 2000a; GORDON; MARTIN, 2000); nuts; nut butters and nutritional bars (GORDON, 2002a); infant formulas (GORDON 2001; $2002 b$ ) and refined vegetable oils; olive oils; and lard hydrogenated fats (OSAWA et al., 2003; 2007a; 2007b).

Strong correlations were found between the kits and the AOCS official methods: $r=0.93$ to 0.95 in a study involving refined vegetable oils, olive oils, and lard and hydrogenated fats using the PeroxySafe ${ }^{\mathrm{TM}}$ kits (OSAWA et al., 2007a); r $=0.99$ for refined vegetable oils and olive oils (OSAWA et al., 2007b), and $\mathrm{r}=0.76$ for frying fats (FOO et al., 2006) with the FaSafe ${ }^{\mathrm{TM}}$ kits; $r=0.92$ for frying fats with the AldeSafe ${ }^{\mathrm{TM}}$ kit (FOO et al., 2006); and $r=0.74$ for frying oils with the Alkal Safe ${ }^{\mathrm{TM}}$ kit (OSAWA et al., 2005b). When compared with the official method for determining \% FFA using an objective instrument (titrator) that eliminates the human errors in the titration end point, the correlation of the FaSafe ${ }^{\mathrm{TM}}$ kits was $\mathrm{r}=0.91$ for refined oils (OSAWA; GONÇALVES, 2006a). Studies with complex matrices, in which lipid is not the only component of the food, are still lacking.

The present work intended to evaluate the quality of pet food samples using the analyses of FFA, PV, AV, and TBA adopting the DiaMed FATS kits and comparing with the AOCS official methods. 


\section{Materials and methods}

200-400 g packs of 18 pet food samples from 6 different kinds of products were examined. The samples showed different degrees of oxidation and none had past their expiration date. The packages were opened only on the first day of analysis. After that, the packages were sealed and the samples were kept frozen.

\subsection{Official methods}

The lipids were extracted from the samples at low temperatures following the procedures described by Gutkoski (1997) and Soares Júnior (2000) with modifications (OSAWA, 2005): sample-petroleum ether ratio of 2:3 (weight/volume) and an increase in the period of contact of the sample with the solvent (overnight in a dark dry place). The extracted lipids were transferred into a dark flask and kept at $-18^{\circ} \mathrm{C}$ until analyzed. They were then immersed in a water bath at $50^{\circ} \mathrm{C}$ with nitrogen flux for defrosting and expelling any remaining solvent.

On the first day of the analyses, the samples were evaluated by the official methods and on the following day by the respective kit. All tests were done in triplicate. The official methods adopted are described below.

\section{Free fatty acids}

Determined by the modified AOCS official method Ca 5a-40 (AOCS, 2004) using $0.2 \mathrm{~g}$ of each sample diluted in $30 \mathrm{~mL}$ of a hot solution of $95 \%$ ethyl alcohol (adding 5\% water to absolute ethyl alcohol). The titulant used was $0.05 \mathrm{M} \mathrm{NaOH}$ solution. Osawa, Gonçalves, and Ragazzi (2006) showed that a reduction in the sample size did not alter the results as compared to an objective method of \% FFA determination by titration.

\section{Peroxide value}

Since using a more dilute titrant solution did not affect the correlation between the kit results and the results of the official method for refined vegetable oils, lard, and hydrogenated fats (OSAWA et al., 2007a), the modification of the AOCS official method Cd 8b-90 (AOCS, 2004) seemed to be a viable alternative. The sample size was also reduced in this case. $0.2 \mathrm{~g}$ of sample was placed in a $100 \mathrm{~mL}$ stoppered conical flask containing $25 \mathrm{~mL}$ of acetic acid: isooctane $3: 2,0.5 \mathrm{~mL}$ of saturated $\mathrm{KI}$ solution, $15 \mathrm{~mL}$ of distilled water, and titration with a $0.001 \mathrm{M}$ sodium thiosulfate solution.

\section{p-anisidine value}

Determined by the AOCS Cd 18-90 method (AOCS, 2004), using 0.2-0.4 g samples, glacial acetic acid and analytical grade isooctane, 99\% p-anisidine (ALDR-A88255, Aldrich) and a quartz cuvette. A blank was prepared for each sample and the samples read in the visible and ultraviolet ranges of the UV/VIS Lambda 20 Spectrophotometer (Perkin Elmer, Germany). In an attempt to eliminate the interference by water, the reagents isooctane, acetic acid, and p-anisidine were purified prior to analysis, as described by Osawa (2005), and their moisture contents were then determined.

\section{Purification of the reagents for the p-anisidine test}

The isooctane was treated with sulfuric acid with occasional agitation for 24 hours. Afterwards, an aqueous solution of $0.1 \mathrm{M}$ potassium permanganate was added and then placed in a separating funnel and washed until $\mathrm{pH}=7.0$. The solution was filtered and distilled, according to Swinehart (1969) and Fessenden and Fessenden (1983), discarding the head and tail. This solution was kept in contact with anhydrous sodium sulfate until the day of the analyses, when it was filtered for use.

The glacial acetic acid used was treated with potassium permanganate in a ratio of $5 \mathrm{~g}$ per $1 \mathrm{~L}$ of acetic acid keeping it in contact for 24 hours. Similar to the procedure with isooctane, the solution was distilled and kept in contact with anhydrous sodium sulfate until used.

The p-anisidine crystals were dried in a vacuum desiccator for 20.5 hours at room temperature and the glacial acetic acid was treated with $0.3 \%$ anhydrous acetic acid after purification according to Morita and Assumpção (2001).

\section{TBA number}

Determined by the AOCS Cd 19-90 method (AOCS, 2004), using $0.15-0.25 \mathrm{~g}$ of samples in $10-\mathrm{mL}$ volumetric flasks, dissolving the samples in analytical grade 1-butanol and 2-thiobarbituric acid (11496-000, Acros Organics). Absorbance readings were obtained from the same equipment used for the p-anisidine test.

\section{Moisture content of the reagents}

After purification, the moisture contents of all reagents used in the p-anisidine and TBA tests were determined in triplicate by the Karl Fischer method AOCS Ca 2e-84 (AOCS, 2004) with alterations (OSAWA, 2005) using the Titroline alpha titrator (Schott, Germany), a $10 \mathrm{~mL}$ burette, a magnetic stirrer TM 125 (Schott, Germany), and the Karl Fischer reagent 9258 containing methoxyethanol in a single solution and containing no pyridine (Merck, Germany). The initial agitation was adjusted to 30 seconds and the titration end point to $30 \mu \mathrm{A}$, when the equipment automatically stopped the transference of the titrant solution. For the water equivalence determination, $20 \mathrm{mg}$ of water was injected into the titration vessel with a 1-mL syringe (Microstat Tuberculin, United States). Except for the $\mathrm{p}$-anisidine, where $200 \mathrm{mg}$ of p-anisidine crystals were used, the size of the samples evaluated was the equivalent to 30 drops (200-500 mg) using a Pasteur pipette.

\subsection{Kits}

The procedures adopted for the analyses using the kits were based on the manufacturer's instructions as described by Osawa (2005) and Osawa and Gonçalves (2006b) consisting of the following steps: i) construction of a calibration curve with reagents called calibrators (the linear coefficient of correlation $r$ must be greater than 0.99); ii) tests with standard solutions of known concentrations called controls; iii) lipid extraction from samples; and iv) tests with samples. 
The lipid extraction was performed by diluting $1 \mathrm{~g}$ of ground sample with a specific reagent (Preparation Reagent) while heating at $40{ }^{\circ} \mathrm{C}$ for 15 minutes and then filtering the diluted lipid in a membrane filter (SAFETY ASSOCIATES, 1998) at $600 \mathrm{mBar}$ for 1 minute.

Each test was performed with $50-150 \mu \mathrm{L}$ of diluted samples, calibrators, or controls; addition of specific reagents (A, B, and $\mathrm{C}$, in that sequence); agitation by inversion in a vortex mixer for 10 minutes (AciSafe ${ }^{\mathrm{TM}} \mathrm{MSA}$ ), 15 minutes (PeroxySafe ${ }^{\mathrm{TM}} \mathrm{MSA}$ ), 90 minutes (AlkalSafe ${ }^{\mathrm{TM}}$ STD), or 120 minutes (AldeSafe ${ }^{\mathrm{TM}} \mathrm{STD}$ ); and readings at $550-570 \mathrm{~nm}$ in a colorimeter (MicroChem ${ }^{\mathrm{TM}}$ Analyser, Source Scientific, USA), which expresses the results in absorbance values and concentration of the analyte tested, calculates the averages and coefficients of variation (CV), and prints out the results immediately.

Reagent A is a solvent. Reagent $\mathrm{B}$ is an acidified xylenolorange solution ( $\mathrm{pH}$ indicator) for the AciSafe and PeroxySafe kits or an acidified indol solution for the AlkalSafe and Aldesafe kits. Reagent $\mathrm{C}$ is only used for the PeroxySafe kit and consists of an acidified iron solution.

The material used for the kit determinations consisted of: dispensers, pipette and tips, glass tubes $(12 \times 75 \mathrm{~mm})$ and caps, vortex mixer, grinder, heating block, filters with membrane, filter holders, vacuum pump, reagents (DiaMed, Switzerland) and colorimeter (MicroChem ${ }^{\mathrm{TM}}$ Analyser, Source Scientific, USA).

Since the results of the kits were on a sample basis, the values for \% FFA, PV, AV, and TBA number had to be converted to a lipid basis. The lipid contents of the samples were determined by acid hydrolysis, in duplicate, as described by Osawa (2005). Acid hydrolysis was required to liberate the lipid covalently bound to the proteins and carbohydrates (SHAHIDI; WANASUNDARA, 1998). Two grammes of ground sample contained in a $250 \mathrm{~mL}$ beaker was dried in an oven at $105^{\circ} \mathrm{C}$ for 1 hour; $45 \mathrm{~mL}$ of boiling water was then added followed by $55 \mathrm{~mL}$ of a concentrated solution of $\mathrm{HCl}: \mathrm{H}_{2} \mathrm{O}$ 2:1 (v/v). The sample was completed digested while heating and then washed, filtered, and dried at $105^{\circ} \mathrm{C}$ for 1 hour. The lipid content was then determined according to the AOCS method Af 3-54 (AOCS, 2004).

\subsection{Statistical analysis}

Initially, some basic statistical parameters were evaluated such as: averages between repetitions, deviations, coefficients of variation, differences between values for the AciSafe ${ }^{\mathrm{TM}} \mathrm{MSA}$ and PeroxySafe ${ }^{\mathrm{TM}}$ MSA kits, and maximum and minimum values.

The linear regression was then studied to compare the FFA values obtained using the DiaMed kits with those obtained using the official method. The software Minitab for Windows version 12.1 (MINITAB REFERENCE GUIDE, 1994; MINITAB USER'S GUIDE, 1994) was used to obtain the linear regression by the Minimum Square Method (MONTGOMERY, 1991; MONTGOMERY; PECK, 1992) with bands of $95 \%$ of confidence and $95 \%$ of prediction (CHARNET et al., 1999; MONTGOMERY; PECK, 1992). The Analysis of Variance was also carried out using the software SAS for Windows version 8.2 (COUNCIL, 1985) in order to validate the linear regression model and to make a comparison of means followed by the use of the Tukey Test at a 5\% level of significance.

\section{Results and discussion}

Hydrolytic rancidity has occurred the samples studied, with increasing FFA formation during storage, as opposed to oxidative rancidity, indicated by the low peroxide values and concentrations of alkenals and malonaldehydes.

The pet food samples analyzed presented lipid contents from $10.4 \pm 0.3$ to $24.9 \pm 1.8 \%(\mathrm{CV}=0.0-15.7 \%)$. The values obtained for the \% FFA, PV, AV, and TBA number were, on a lipid basis, respectively, $4.6 \pm 0.1$ to $28.0 \pm 0.6 \%$ oleic acid $(\mathrm{CV}=0.4-4.8 \%$ ); $1.4 \pm 0.1$ to $6.8 \pm 0.3 \mathrm{meq} \mathrm{O}_{2} / \mathrm{kg}(\mathrm{CV}=0.9-14.7 \%) ;-9.3 \pm 0.6$ to $46.2 \pm 10.8$ (AV; $\mathrm{CV}=6.5-900.0 \%)$; and $0.009 \pm 0.001$ to $0.072 \pm 0.004$ (TBA; $\mathrm{CV}=2.5-22.7 \%$ ) using the AOCS official methods.

For the measurements determined using the kits, the following values were obtained on a lipid basis: $4.2 \pm 0.1$ to $16.8 \pm 0.9 \%$ oleic acid $(\mathrm{CV}=1.0-8.3 \%) ; 0.4 \pm 0.0$ to $2.9 \pm 0.1 \mathrm{meq} \mathrm{O}_{2} / \mathrm{kg}(\mathrm{CV}=0.0-9.2 \%) ; 105 \pm 8$ to $364 \pm 19 \mathrm{nmol}$ of alkenals $/ \mathrm{kg}(\mathrm{CV}=0.0-8.7 \%)$, and $8 \pm 0$ to $164 \pm 14 \mathrm{nmol}$ of malonaldehyde $/ \mathrm{kg}(\mathrm{CV}=0.0-10.5 \%)$, respectively, for the AciSafe $^{\mathrm{TM}}$ MSA, PeroxySafe ${ }^{\mathrm{TM}}$ MSA, AlkalSafe ${ }^{\mathrm{TM}}$ STD, and AldeSafe ${ }^{\text {TM }}$ STD kits.

The differences between the values obtained with the AciSafe ${ }^{\mathrm{TM}}$ MSA kit and the modified official method AOCS Ca 5a-40 (OSAWA; GONÇALVES, 2006a; OSAWA et al., 2006) ranged from -51.6 to $77.2 \%$, and the differences between the PeroxySafe ${ }^{\mathrm{TM}}$ MSA kit and the modified official method AOCS Cd 8b-90 (OSAWA et al., 2007a) ranged from -86.5 to $48.9 \%$.

For a kit to be considered reliable, the results obtained from it must be accurate and precise. In this study, the precision was evaluated from the $\mathrm{CV}$ values while the correlation (or otherwise) with the official methods determined if the kit was accurate (or otherwise).

Both set of methods showed acceptable repeatability (precision) according to the low values for the CVs found for all the kits tested except for the p-anisidine test that was subjected to water interference even after purification of all reagents involved prior to the analyses.

Even though the samples had past the expiration date, in general, they had undergone little oxidation due to the antioxidant system used in the formulation of the pet foods. Six samples (samples M, N, P, Q, R, and S) presented alkenal concentrations below the detection limit of the kit adopting the minimum possible dilution (Table 3 ). The same occurred with the AldeSafe ${ }^{\mathrm{TM}}$ STD since another six samples (samples $\mathrm{G}, \mathrm{H}$, $\mathrm{J}, \mathrm{K}, \mathrm{L}$, and $\mathrm{N}$ ) showed malonaldehyde concentrations below the detection limit (Table 4). Nevertheless, the determinations made with these kits were more sensitive as they discriminated a larger number of samples in the Tukey test than the official methods (Tables 3 and 4 ). The results for PV obtained using the kit were also small $\left(\mathrm{PV}<3.0 \pm 0.1 \mathrm{meq}_{2} / \mathrm{kg}\right)$. 
Table 3. Alkenal concentrations in nmol. $\mathrm{kg}^{-1}$ obtained using the AlkalSafe STD ${ }^{\mathrm{TM}}$ kit and p-anisidine values determined by the AOCS official method Cd 18-90, in the pet food samples, presented in decreasing order for each method.

\begin{tabular}{|c|c|c|c|}
\hline Sample & $\begin{array}{c}\text { Alkenal concentration } \\
\left(\mathrm{nmol} \cdot \mathrm{kg}^{-1}\right)\end{array}$ & Sample & $\begin{array}{c}\mathrm{p} \text {-anisidine } \\
\text { value }\end{array}$ \\
\hline $\mathrm{K}$ & $364 \pm 19^{\mathrm{a}}$ & $\mathrm{D}$ & $46.2 \pm 10.8^{\mathrm{a}}$ \\
\hline $\mathrm{L}$ & $285 \pm 0^{\mathrm{b}}$ & $\mathrm{O}$ & $27.3 \pm 1.8^{\mathrm{b}}$ \\
\hline $\mathrm{F}$ & $236 \pm 15^{c}$ & M & $17.3 \pm 2.1^{\mathrm{bc}}$ \\
\hline $\mathrm{J}$ & $234 \pm 0^{c}$ & Q & $12.8 \pm 2.5^{\mathrm{cd}}$ \\
\hline B & $191 \pm 17^{\mathrm{d}}$ & $\mathrm{R}$ & $12.8 \pm 2.8^{\mathrm{cd}}$ \\
\hline $\mathrm{O}$ & $185 \pm 12^{\mathrm{de}}$ & $\mathrm{P}$ & $10.0 \pm 3.2^{\text {cde }}$ \\
\hline G & $174 \pm 14^{\mathrm{de}}$ & $\mathrm{J}$ & $8.9 \pm 4.5^{\text {cde }}$ \\
\hline $\mathrm{H}$ & $167 \pm 9^{\mathrm{de}}$ & $\mathrm{N}$ & $7.6 \pm 1.2^{\text {cdef }}$ \\
\hline A & $161 \pm 12^{\mathrm{de}}$ & $S$ & $6.8 \pm 1.4^{\text {cdef }}$ \\
\hline $\mathrm{E}$ & $153 \pm 12^{\mathrm{ef}}$ & $\mathrm{B}$ & $5.6 \pm 2.6^{\mathrm{def}}$ \\
\hline $\mathrm{D}$ & $124 \pm 8^{\mathrm{fg}}$ & $\mathrm{K}$ & $1.4 \pm 3.0^{\mathrm{efg}}$ \\
\hline $\mathrm{C}$ & $105 \pm 8^{g}$ & $\mathrm{E}$ & $0.9 \pm 3.2^{\mathrm{efg}}$ \\
\hline M & * & $\mathrm{C}$ & $0.5 \pm 4.5^{\mathrm{efg}}$ \\
\hline $\mathrm{N}$ & * & A & $-3.2 \pm 1.7^{\mathrm{fg}}$ \\
\hline $\mathrm{P}$ & * & G & $-7.1 \pm 2.8^{\mathrm{g}}$ \\
\hline Q & * & $\mathrm{H}$ & $-7.3 \pm 0.7^{\mathrm{g}}$ \\
\hline $\mathrm{R}$ & * & $\mathrm{F}$ & $-8.6 \pm 2.7^{g}$ \\
\hline S & * & $\mathrm{L}$ & $-9.3 \pm 0.6^{\mathrm{g}}$ \\
\hline
\end{tabular}

*Samples with alkenal concentrations below the detection limit of the kit $\left(7 \mathrm{nmol} . \mathrm{mL}^{-1}\right)$; and samples with the same letter in the same column are not significantly different $(\alpha=0.05)$.

Table 4. Malonaldehyde concentrations in nmol. $\mathrm{kg}^{-1}$ obtained using the AldeSafe STD ${ }^{\mathrm{TM}}$ kit and TBA values determined by the AOCS official method Cd 19-90, in the pet food samples, presented in decreasing order for each method.

\begin{tabular}{|c|c|c|c|}
\hline Sample & $\begin{array}{l}\text { Malonaldehyde con- } \\
\text { centration }\left(\text { nmol. }^{-1}{ }^{-1}\right)\end{array}$ & Sample & $\begin{array}{c}\text { TBA } \\
\text { number }\end{array}$ \\
\hline$S$ & $138.7 \pm 12.0^{\mathrm{a}}$ & $\mathrm{E}$ & $0.072 \pm 0.004^{\mathrm{a}}$ \\
\hline M & $106.9 \pm 8.2^{\mathrm{b}}$ & B & $0.065 \pm 0.002^{\mathrm{ab}}$ \\
\hline $\mathrm{O}$ & $84.6 \pm 6.8^{c}$ & $\mathrm{D}$ & $0.058 \pm 0.004^{\mathrm{b}}$ \\
\hline Q & $71.5 \pm 4.5^{\mathrm{cd}}$ & $\mathrm{F}$ & $0.056 \pm 0.002^{b c}$ \\
\hline $\mathrm{E}$ & $56.8 \pm 2.8^{\mathrm{de}}$ & G & $0.056 \pm 0.004^{\mathrm{bc}}$ \\
\hline $\mathrm{F}$ & $46.8 \pm 4.8^{\mathrm{ef}}$ & $\mathrm{O}$ & $0.046 \pm 0.002^{\mathrm{cd}}$ \\
\hline $\mathrm{D}$ & $46.6 \pm 2.4^{\mathrm{ef}}$ & $\mathrm{N}$ & $0.041 \pm 0.006^{\mathrm{de}}$ \\
\hline $\mathrm{R}$ & $43.1 \pm 4.0^{\mathrm{ef}}$ & $\mathrm{C}$ & $0.040 \pm 0.004^{\mathrm{de}}$ \\
\hline $\mathrm{C}$ & $35.5 \pm 1.6^{\mathrm{fg}}$ & A & $0.040 \pm 0.001^{\mathrm{de}}$ \\
\hline $\mathrm{P}$ & $25.2 \pm 2.0^{\mathrm{gh}}$ & S & $0.040 \pm 0.001^{\mathrm{de}}$ \\
\hline A & $19.1 \pm 2.0^{\mathrm{hi}}$ & M & $0.040 \pm 0.001^{\mathrm{de}}$ \\
\hline B & $7.5 \pm 0.0^{\mathrm{i}}$ & $\mathrm{R}$ & $0.038 \pm 0.001^{\mathrm{de}}$ \\
\hline G & * & Q & $0.036 \pm 0.002^{\mathrm{de}}$ \\
\hline $\mathrm{H}$ & * & $\mathrm{H}$ & $0.034 \pm 0.006^{\mathrm{e}}$ \\
\hline $\mathrm{J}$ & * & $\mathrm{P}$ & $0.033 \pm 0.001^{\mathrm{e}}$ \\
\hline K & * & $\mathrm{J}$ & $0.032 \pm 0.003^{\mathrm{ef}}$ \\
\hline $\mathrm{L}$ & * & $\mathrm{K}$ & $0.022 \pm 0.005^{f}$ \\
\hline $\mathrm{N}$ & * & $\mathrm{L}$ & $0.009 \pm 0.001^{\mathrm{g}}$ \\
\hline
\end{tabular}

* Samples with alkenal concentrations below the detection limit of the kit $\left(0 \mathrm{nmol} \cdot \mathrm{mL}^{-1}\right)$; and samples with the same letter in the same column are not significantly different $(\alpha=0.05)$.
Due to the small range of values for PV, p-anisidine, and TBA the correlation studies of these kits with the official methods were not done.

The results obtained with the AciSafe ${ }^{\mathrm{TM}}$ MSA kit were accurate since they correlated highly (Figure 1) with the results of the modified official methods AOCS Ca 5a-40 (OSAWA; GONÇALVES, 2006a; OSAWA et al., 2006) when pet food samples were used even though a correction factor of 1.25 (Tables 5, 6 and 7) had to be used for the kit results, so that the $\%$ FFA percentages became equivalent.

A correlation coefficient $r$ of $0.88\left(R^{2}=0.78\right)$ and the equation $y=0.49 x+3.44$ (Figure 1 ) was obtained for the correlation between the AciSafe ${ }^{\mathrm{TM}}$ MSA kit and the official method for the FFA determination. The linear model was validated by the

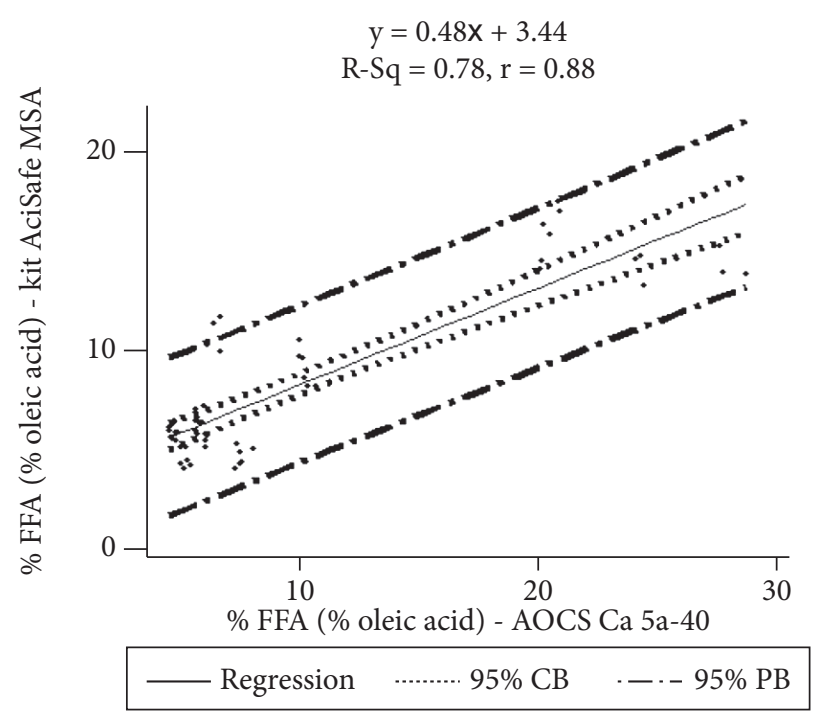

Figure 1. Graph of the correlation between \% FFA of pet food samples in $\%$ oleic acid, as determined by the AciSafe ${ }^{\mathrm{TM}} \mathrm{MSA}$ and the modified official method AOCS Ca 5a-40, with bands of $95 \%$ of confidence (CB) and $95 \%$ of prediction $(\mathrm{PB})$.

Table 5. ANOVA test for the comparison of means - AciSafe ${ }^{\mathrm{TM}}$ MSA kit.

\begin{tabular}{lrrrccc}
\hline \multicolumn{1}{c}{$\begin{array}{c}\text { Source of } \\
\text { variation }\end{array}$} & SS & DF & MSS & $\mathrm{F}_{\text {Calc }}$ & $\mathrm{F}_{\text {Tab }}$ & $\operatorname{Pr}>\mathrm{F}$ \\
\hline Methodology & 87.27 & 1 & 87.27 & 15.86 & $\cong 3.95(\alpha=5 \%)$ & 0.0001 \\
Sample & 3296.21 & 17 & 193.89 & & & \\
Residual error & 489.54 & 89 & 5.50 & & & \\
\hline SS = sum of squares; DF = degrees of freedom; and MSS = mean of sum of squares.
\end{tabular}

Table 6. ANOVA test for the comparison of means applying a correction factor of 1.20 to the results obtained with the AciSafe ${ }^{\mathrm{TM}}$ MSA kit.

\begin{tabular}{lrrrrcc}
\hline $\begin{array}{l}\text { Source of } \\
\text { variation }\end{array}$ & \multicolumn{1}{c}{ SS } & DF & MSS & $\mathrm{F}_{\text {Calc }}$ & $\mathrm{F}_{\text {Tab }}$ & $\operatorname{Pr}>\mathrm{F}$ \\
\hline $\begin{array}{l}\text { Methodology } \\
\text { Sample }\end{array}$ & 0.41 & 1 & 0.41 & 0.09 & $\cong 3.95(\alpha=5 \%)$ & 0.7647 \\
Residual error & 403.80 & 89 & 4.54 & & & \\
Total & 4173.78 & 107 & & & & \\
\hline
\end{tabular}

$\mathrm{SS}=$ sum of squares; DF = degrees of freedom; and MSS = mean of sum of squares 
ANOVA test with a highly significant F-value $\left(\mathrm{F}_{\text {calc }}>\mathrm{F}_{\mathrm{Tab}}\right)$ with $5 \%$ of significance, as it can be seen in Table 8 .

The r-value of 0.88 is an intermediate value if compared with previous studies: $\mathrm{r}=$ 0.76-0.99 (FOO et al., 2006; OSAWA; GONÇALVES, 2006a; OSAWA et al., 2007b). For refined vegetable oils and olive oils, no correction factor was needed (OSAWA et al., 2007b). However, when a titrator was used for the official method determination, the results with the kits needed to be corrected by a factor of 0.8 (OSAWA; GONÇALVES, 2006a). Possibly, the darker color of the lipid extracted interfered in the visualization of the titration end point resulting in the use of more titrant solution (OSAWA et al., 2006). Thus, it contributed to the higher value of the correction factor if compared to that required for refined and olive oils or when a titrator was used instead of the analyst's perception.

A comparison of the means obtained for \% FFA with the AciSafe $^{\mathrm{TM}}$ MSA and the official method, using ANOVA test, showed significant differences at the $5 \%$ level of significance (Table 5).

By trial and error, multiplying the results obtained with the kit by 1.20 and 1.30, there were no differences between the methods at the 5\% level of significance (Tables 6 and 7), and thus the recommended average correction factor is 1.25 .

For the peroxide value determination, the visualization of the end point of titration was difficult overestimating the PVs. According to Table 9, the PV values obtained by the modified official method AOCS Cd 8b-90 (OSAWA et al., 2007a) were, in general, higher than the values obtained by the PeroxySafe ${ }^{\mathrm{TM}}$ MSA kit. In a previous study (OSAWA et al., 2007a), the dilution of the titrant led to imprecision in the PVs, especially for $\mathrm{PV}<2 \mathrm{meq}_{2} / \mathrm{kg}$, but the correlation between the methods did not suffer any interference. In addition, the results obtained with the kit stressed the very small differences detected discriminating a higher number of significantly different samples from the AOCS official method (Table 9). This suggests that the kit is more sensitive than the AOCS method although only a small range of PV was evaluated.

Table 7. ANOVA test for the comparison of means applying a correction factor of 1.30 to the results obtained with the AciSafe ${ }^{\mathrm{TM}}$ MSA kit

\begin{tabular}{lccrccc}
\hline $\begin{array}{l}\text { Source of } \\
\text { variation }\end{array}$ & SS & DF & MSS & $\mathrm{F}_{\text {Calc }}$ & $\mathrm{F}_{\text {Tab }}$ & $\operatorname{Pr}>\mathrm{F}$ \\
\hline Methodology & 13.77 & 1 & 13.77 & 3.28 & $\cong 3.95(\alpha=5 \%)$ & 0.0737 \\
Simple & 4019.31 & 17 & 236.43 & & & \\
Residual error & 374.3 & 89 & 4.21 & & & \\
Total & 4407.38 & 107 & & & & \\
\hline
\end{tabular}

SS = sum of squares; DF = degrees of freedom; and MSS = mean of sum of squares.

Table 8. ANOVA test for the linear regression model - AciSafe ${ }^{\mathrm{TM}}$ MSA kit.

\begin{tabular}{lrrrccc}
\hline \multicolumn{1}{c}{$\begin{array}{c}\text { Source of } \\
\text { variation }\end{array}$} & SS & DF & MSS & $\mathrm{F}_{\text {Calc }}$ & $\mathrm{F}_{\text {Tab }}$ & $\mathrm{p}$ \\
\hline Regression & 683.36 & 1 & 683.36 & 179.85 & $\approx 4.04(\alpha=5 \%)$ & 0.000 \\
Residual error & 197.58 & 52 & 3.80 & & & \\
Total & 880.94 & 53 & & & & \\
\hline
\end{tabular}

SS = sum of squares; DF = degrees of freedom; and MSS = mean of sum of squares.
The negative values obtained in the $\mathrm{p}$-anisidine test (Table 3) represent an unreal condition and can be attributed to the water present in the samples and reagents even after being submitted to the treatments described. This interfered in the test leading to lower results. The maximum value permitted for moisture in the samples is $0.1 \%$ (AOCS, 2004). After purification, the p-anisidine crystals had $1.2 \pm 0.1 \%$ of moisture by the Karl Fischer method whilst the water contents of the purified glacial acetic acid and purified isooctane were, respectively, $0.29 \pm 0.02 \%$ and $0.05 \pm 0.01 \%$. In the TBA test, the 1-butanol used had $0.28 \pm 0.04 \%$ of moisture, so it did not exceeded the limit of $0.5 \%$ (AOCS, 2004). Thus, the p-anisidine test suffered from an inherent interference by the water and reagents present in the samples (OSAWA et al., 2005b), and all attempts to reduce it failed.

Some difficulty was found using the AlkalSafe ${ }^{\text {TM }}$ STD kit. The value for the control was much lower than the expected range of 14 to $15 \mathrm{nmol} . \mathrm{kg}^{-1}$ obtaining values of $3.3 \pm 0.3 \mathrm{nmol} . \mathrm{kg}^{-1}$ and $4.7 \pm 1.1 \mathrm{nmol} . \mathrm{kg}^{-1}$ in the repetition of the test. This could be explained by the fact that the AlkalSafe ${ }^{\mathrm{TM}}$ STD kit was the only one in which the calibrators were ready to read solutions and did not depend on the reagents used in the control or in the sample tests. Perhaps, the supplier should improve those kits making adaptations in order to provide more reliable results although the repeatability of the kit was appropriate $(\mathrm{CV}<10 \%)$.

The TBA test generated less accurate results and mainly to a numerical order of $10^{-2}$. The AldeSafe $\mathrm{STD}^{\mathrm{TM}} \mathrm{kit}$, on the other hand, provided results to numerical orders of $10^{\circ}$ to $10^{2}$ making it easier to differentiate the samples from the malonaldehyde concentration values (Table 4).

Table 9. Peroxide values (decreasing order) obtained using the PeroxySafe MSA ${ }^{\mathrm{TM}}$ kit and the modified official method AOCS Cd $8 \mathrm{~b}-90$, in $\mathrm{meq}_{2} / \mathrm{kg}$, for the pet food samples.

\begin{tabular}{cccc}
\hline Sample & $\begin{array}{c}\mathrm{PV} \\
\left(\mathrm{meq}_{2} / \mathrm{kg}\right)-\mathrm{kit}\end{array}$ & Sample & $\begin{array}{c}\mathrm{PV} \\
\left(\mathrm{meq}_{2} / \mathrm{kg}\right)-\mathrm{OCS}\end{array}$ \\
\hline $\mathrm{Q}$ & $2.9 \pm 0.1^{\mathrm{a}}$ & $\mathrm{K}$ & $6.8 \pm 0.3^{\mathrm{a}}$ \\
$\mathrm{A}$ & $2.5 \pm 0.0^{\mathrm{b}}$ & $\mathrm{A}$ & $5.3 \pm 0.3^{\mathrm{b}}$ \\
$\mathrm{R}$ & $2.5 \pm 0.0^{\mathrm{b}}$ & $\mathrm{E}$ & $4.7 \pm 0.0^{\mathrm{bc}}$ \\
$\mathrm{P}$ & $1.5 \pm 0.0^{\mathrm{c}}$ & $\mathrm{B}$ & $4.6 \pm 0.6^{\mathrm{c}}$ \\
$\mathrm{B}$ & $1.4 \pm 0.1^{\mathrm{cd}}$ & $\mathrm{R}$ & $4.3 \pm 0.2^{\mathrm{c}}$ \\
$\mathrm{C}$ & $1.3 \pm 0.1^{\mathrm{d}}$ & $\mathrm{C}$ & $2.9 \pm 0.1^{\mathrm{d}}$ \\
$\mathrm{N}$ & $1.1 \pm 0.1^{\mathrm{e}}$ & $\mathrm{L}$ & $2.9 \pm 0.3^{\mathrm{d}}$ \\
$\mathrm{J}$ & $1.0 \pm 0.1^{\mathrm{ef}}$ & $\mathrm{S}$ & $2.7 \pm 0.0^{\mathrm{de}}$ \\
$\mathrm{E}$ & $0.9 \pm 0.1^{\mathrm{fg}}$ & $\mathrm{J}$ & $2.4 \pm 0.0^{\mathrm{def}}$ \\
$\mathrm{S}$ & $0.8 \pm 0.0^{\mathrm{fgh}}$ & $\mathrm{G}$ & $2.1 \pm 0.1^{\mathrm{def}}$ \\
$\mathrm{F}$ & $0.8 \pm 0.1^{\mathrm{ghi}}$ & $\mathrm{O}$ & $2.1 \pm 0.2^{\mathrm{def}}$ \\
$\mathrm{L}$ & $0.7 \pm 0.0^{\mathrm{hij}}$ & $\mathrm{Q}$ & $1.9 \pm 0.1^{\mathrm{ghh}}$ \\
$\mathrm{O}$ & $0.7 \pm 0.0^{\mathrm{hij}}$ & $\mathrm{N}$ & $1.9 \pm 0.3^{\mathrm{fgh}}$ \\
$\mathrm{D}$ & $0.7 \pm 0.0^{\mathrm{hij}}$ & $\mathrm{F}$ & $1.8 \pm 0.1^{\mathrm{gh}}$ \\
$\mathrm{H}$ & $0.6 \pm 0.0^{\mathrm{ij}}$ & $\mathrm{H}$ & $1.7 \pm 0.1^{\mathrm{gh}}$ \\
$\mathrm{G}$ & $0.6 \pm 0.0^{\mathrm{ij}}$ & $\mathrm{M}$ & $1.6 \pm 0.1^{\mathrm{gh}}$ \\
$\mathrm{M}$ & $0.6 \pm 0.0^{\mathrm{jk}}$ & $\mathrm{D}$ & $1.6 \pm 0.0^{\mathrm{gh}}$ \\
$\mathrm{K}$ & $0.4 \pm 0.0^{\mathrm{k}}$ & $\mathrm{P}$ & $1.4 \pm 0.1^{\mathrm{h}}$ \\
\hline
\end{tabular}

Samples with the same letter in the same column are not significantly different $(\alpha=0.05)$. 
The TBA test is not an accurate measurement although it is widely used and well known. The heating under acidic conditions employed in the TBA test may form substances that react with the 2-thiobarbituric acid overestimating the TBA number (OSAWA et al., 2005a; WHITE, 1995). The correlation coefficient of $r=0.92$ obtained for the AldeSafe ${ }^{\mathrm{TM}}$ kit when applied to frying fats and compared with the AOCS official method, may have been possible due to a modification in the method. The authors adapted the method to achieve results to the magnitude of nmol.mL ${ }^{-1}$, similar to the kit, instead of the adimensional values given by the official TBA test (FOO et al., 2006). No other study was found correlating the results of this kit with those of the AOCS official method.

The main advantages of applying kits to monitor the quality of pet foods are the significant reduction in the sample size, since lipid is not the only compound present, and time and solvents saved for the extracting the lipids and performing the analysis. Using the kits, the lipids were extracted from the samples in 15 minutes with no more than $5 \mathrm{~mL}$ of solvent (OSAWA, 2005; OSAWA; GONÇALVES, 2006b).

The lipid extraction procedure adopted in this experiment for the determinations with the official methods was time-consuming, presented low yields since no heating was allowed, had a lot of steps and used a lot of equipment and materials. Moreover, the large amounts of samples and reagents needed for the lipid extraction and subsequent conventional analyses make shelf-life studies unfeasible from the economic point of view, especially when the lipid content is very low. The DiaMed FATS kits could be used with minimum residue generation, smaller amounts of sample, less time devoted to analysis, more precise results, and no need for a laboratory fully equipped with sophisticated equipment.

\section{Conclusions}

The pet food samples evaluated presented good quality in terms of oxidative rancidity although they would be discarded for having passed the expiration date before being analyzed. This means that the sector is concerned about the quality of the products being commercialized.

The DiaMed FATS kits are precise and recommended for shelf-life studies of samples which require lipid extraction prior to analysis since they are fast, involve significantly less sample and reagents, are compact and do not demand large areas or sophisticated equipment, and offer better work conditions and less risks to the analyst.

The results generated by this study suggested that they represent good alternatives in cases where the lipid content is low or the stage of oxidative rancidity is minimum considering the limitations in sensitivity of the official methods.

\section{Acknowledgments}

The authors are grateful for the financial support provided by the foundations CAPES (Brazilian research supporting foundation) and Diamed LatinoAmérica, Diamed AG (Switzerland), for the technical support provided by Mr. Laércio de Melo and Ms. Evelyne de Groove, and to Total Alimentos (Brazil) for the pet food samples provided.

\section{References}

ALIMENTOS PARA BICHOS DE ESTIMAÇÃO. Herbário, sept. 16th, 2002. See: http://www.herbario.com.br/bot/agri/alipet.htm November 1st, 2004.

AOCS. Official methods and recommended practices of the American Oil Chemists' Society. Champaign: American Oil Chemists' Society, 2004.

BELITZ, H. D.; GROSCH, W. Food chemistry. 2nd edition. Berlin: Springer, 1999. Chap. 3.

CHARNET, R.; FREIRE, C. A. L.; CHARNET, R. M. R.; BONVINO, $\mathrm{H}$. Análise de modelos de regressão linear. Campinas: Editora da Unicamp, 1999.

COUNCIL, K. A. Analysis of variance. In: HELWIG, J.T. (Ed.). SAS Introductory guide. 3rd edition. Cary: SAS Institute Inc., 1985. p. 55-60.

CUTAIT, M. S. Global 21, sept. 24th, 2004. (Interview). See http://www. global21.com.br/entrevistas/entrevista.asp?cod=242 November 1st, 2004.

DOBARGANES, M. C.; VELASCO, J. Analysis of lipid hydroperoxides. Journal of Lipid Science and Technology, v. 104, n. 7, p. 420-428, 2002.

FESSENDEN, R. J.; FESSENDEN, J. S. Techniques and experiments for organic chemistry. Boston: Willard Grant, 1983.

FOO, S. Y.; CUPPETT, F.; SCHLEGEL, V. Evaluation of SafTestTM methods for monitoring frying oil quality. Journal of the American Oil Chemists' Society, v. 83, n. 1, p. 15-20, 2006.

GÓMEZ-PIÑOL, J. M.; BORONAT, M. C. de la T. Influencia de la tecnología en nutritivo de los alimentos: lípidos. Alimentaria, v. 204, p. 15-21, 1989.

GORDON, V. C. Fat content and fat quality in nuts and nut butters. In: IFT ANNUAL MEETING, 2002a, Anaheim. Anais eletrônicos... Anaheim, 2002. See: http://ift.confex.com/ift/2002/techprogram/ paper_11120.htm July 22th, 2003.

. Electronic publication [personal communication]. Message received by<cibelec@fea.unicamp.br> in January 20 th, 2004.

Emerging new techniques for food quality assessment. In: INSTITUTE OF FOOD TECHNOLOGISTS (IFT) ANNUAL MEETING, 2000a, Dallas. Resumos... Dallas: Institute of Food Technologists, 2000.

Evaluation of antioxidant efficacy in treated and untreated oils and snacks using rapid membrane separation technology. In: IFT ANNUAL MEETING, 2000b, Dallas. Anais eletrônicos... Dallas, 2000. See: http://ift.confex.com/ift/2000/techprogram/ July 22th, 2003.

Micro-analytical membrane technology to evaluate infant formula quality and monitor shelf life of infant formulas. IN: IFT ANNUAL MEETING, 2001, New Orleans. Anais eletrônicos... New Orleans, 2001. See: http://ift.confex.com/ift/2001/techprogram/ meeting_2001.htm July 22th, 2003.

. Quality and stability testing of infant formulas. IN: IFT ANNUAL MEETING, 2002b, Anaheim. Anais eletrônicos... Anaheim, 2002. See: http://ift.confex.com/ift/2002/techprogram/ paper_11113.htm July 22th, 2003.

GORDON, V. C.; ALIFF, S.; LEE, H. Monitoring frying oils and fried food products using a membrane separation system. In: AMERICAN OIL CHEMISTS' SOCIETY (AOCS) ANNUAL MEETING FRYING OIL QUALITY II SESSION, 2000. Resumos... San Diego: American Oil Chemists' Society, 2000.

GORDON, V. C.; MARTIN, D. New method using membrane separation to test refined oils for lipid peroxides $(0,01$ to $2,0 \mathrm{meq} / \mathrm{kg})$, free fatty acids $(0,03$ to $0,3 \%)$, and antioxidant concentrations (ppm). IN: AMERICAN OIL CHEMISTS' SOCIETY (AOCS) ANNUAL 
MEETING - GENERAL ANALYTICAL II SESSION, 2000. Resumos... San Diego: American Oil Chemists' Society, 2000.

GRAY, J. I. Measurement of lipid oxidation: a review. Journal of the American Oil Chemists' Society, v. 55, n. 6, p. 539-546, jun. 1978.

GUTKOSKI, L. C. Características tecnológicas de frações de moagem de aveia e efeito de umidade e temperatura de extrusão na sua estabilidade. Campinas, 1997. 241p. Thesis (Food Technology Doctorate) - Food Engineering College, Campinas State University (UNICAMP).

HAMILTON, R. J.; ROSELL, J. B (Ed.). Analysis of oils and fats. London: Elsevier, 1986.

HUI, Y. H. (Ed.). Bailey's industrial oil \& fat products. New York: John Wiley, 1996. v. 3.

LEA, C. H. The oxidative deterioration of food lipids. In: SCHULTZ, H. W. Symposium on foods: lipids and their oxidation. Westport: AVI, 1962. p 3-29.

MESQUITA, A. C. Bichos de estimação, oct. 09th, 2004. See: http:// www.noolhar.com/opovo/cienciaesaude/408046.html November 1 st, 2004

MINITAB REFERENCE GUIDE: release 10 for windows. Pennsylvania: Minitab Inc., 1994. v. 1.

MINITAB USER'S GUIDE: release 10 for windows. Pennsylvania: Minitab Inc., 1994.

MONTGOMERY, D. C. Design and analysis of experiments. 3rd edition. Singapure: John Wiley, 1991.

MONTGOMERY, D. C.; PECK, E. A. Introduction to linear regression analysis. 2nd edition. New York: John Wiley, 1992.

MORITA, T.; ASSUMPÇÃO, R. M. Manual de soluções, reagentes \& solventes: padronização, preparação, purificação. 11th edition. São Paulo: Edgard Blücher, 2001.

NAWAR, W. W. Lipids. In FENNEMA, O. R. (Ed.). Food chemistry. 3rd edition. New York: Marcel Dekker, 1996. Chap. 5, p 225-320.

OSAWA, C. C. Testes rápidos (kits) para avaliação da qualidade de óleos, gorduras e produtos que os contenham e sua correlação com os métodos oficiais da AOCS. Campinas, 2005. 403p. Dissertation (Food Technology Master) - Food Engineering College, Campinas State University (UNICAMP).

OSAWA, C. C.; FELICIO, P. E.; GONÇALVES, L. A. G. Teste de TBA aplicado a carnes e derivados: métodos tradicionais, modificados e alternativos. Química Nova, v. 28, n. 4, p. 655-663, 2005a. See: http://www.scielo.br/scielo.php?script=sci_arttext\&pid=s0100-4 0422005000400019\&lng =en\&nrm=isso (DOI: $10.1590 /$ s0100$40422005000400019)$ June 6th, 2007.

OSAWA, C. C.; GONÇALVES, L. A. G. Evaluación de ácidos grasos libres presentes en aceites vegetales a través de kits rápidos y técnica potenciométrica de detección. Aceites y Grasas, v. 1, n. 62, p. 158-163, 2006a.

. Oxidación lipídica y nuevos métodos analíticos de detección. Aceites y Grasas, v. 2, n. 63, p. 330-338, 2006b.

OSAWA, C. C.; GONÇALVES, L. A. G.; GRIMALDI, R.; MELO, L. Resultados preliminares de novos estudos do sistema Diamed F.A.T.S. na determinação do índice de peróxidos (PV) e ácidos graxos livres (AGL) de óleos refinados, óleos degomados e azeites de oliva. In: SIMPÓSIO INTERNACIONAL "TENDÊNCIAS E INOVAÇÕES EM TECNOLOGIA DE ÓLEOS E GORDURAS”, 1, 2003, Campinas. Resumos... Campinas: Sociedade Brasileira de Óleos e Gorduras, 2003. 1 CD ROM. Word for Windows.

OSAWA, C. C.; GONÇALVES, L. A. G.; RAGAZZI, S. Determination of hydroperoxides in oils and fats using kits. Journal of the Science of Food and Agriculture, v. 87, n. 9, p. 1659-1666, 2007a.
See: http://www3.interscience.wiley.com/cgi-bin/jissue/114275747 (DOI: 10.1002/jsfa.2870) June 6th, 2007.

Correlation between free fatty acids of vegetable oils evaluated by rapid tests and by the official method. Journal of Food Composition and Analysis, v. 20, n. 9, p. 523-528, $2007 \mathrm{~b}$. See: www.elsevier.com/locate/jfca (DOI:10.1016/j.jfca.2007.02.002) June 6th, 2007.

Monitoramento de óleo de fritura através de kit alternativo ao teste de p-anisidina. In: SIMPÓSIO INTERNACIONAL TENDÊNCIAS E INOVAÇÕES EM TECNOLOGIA DE ÓLEOS E GORDURAS, 2, 2005b, Florianópolis. Resumos... Florianópolis: Sociedade Brasileira de Óleos e Gorduras, 2005. 1 CD ROM. Word for Windows.

. Titulação potenciométrica aplicada na determinação de ácidos graxos livres de óleos e gorduras comestíveis. Química Nova, v. 29, n. 3, p. 593-599, 2006. See: http://www.scielo.br/scielo. php?script $=$ sci_arttext\&pid $=$ s0100-40422006000300031\&lng $=$ en \&nrm=isso (DOI: 10.1590/s0100-40422006000300031) June 6th, 2007.

SAFETY ASSOCIATES. John Sorensen, Michal Mittelstein, Soheila Mirhashemi, Virginia C. Gordon, Bennett W. Root Jr., Barbara J. Peasley, John F. Elias. Method and apparatus for determining specific analytes in various matrices. US n. PI 4197235, feb. 27th, 2004, oct. 07th, 2004.

. Soheila Mirhashemi, Michal Mittelstein, John Sorensen, John F. Elias, Virginia C. Gordon. Method and apparatus for determining specific analytes in foods and other complex matrices. CA n. PI 2267226, sept 30th, 1997, apr. 09th, 1998.

Virginia C. Gordon, Bennett W. Root Jr., Barbara J. Peasley, John F. Elias, John Sorensen, Michal Mittelstein, Soheila Mirhashemi. Method and apparatus for determining specific analytes in various matrices. AU n. PI 759265, oct. 21th 1998, apr. 29th, 1999.

. Virginia C. Gordon, Bennett W. Root Jr., Barbara J. Peasley, John F. Elias, John Sorensen, Michal Mittelstein, Soheila Mirhashemi. Method and apparatus for determining specific analytes in various matrices. US n. PI 3064423, mar. 26th, 2003, apr. 03rd, 2003.

SAFTEST. Certificate no 030405: FaSafeTM Standard test kit. Arizona: SafTest Inc, 2003a. See http://www.aoac.org/testkits/ certificates/030501certificate.pdf February 13th, 2004.

SAFTEST. Certificate no 030501: PeroxySafeTM Standard test kit. Arizona: SafTest Inc, 2003b. See http://www.aoac.org/testkits/ certificates/030405certificate.pdf February 13th, 2004.

SHAHIDI, F.; WANASUNDARA, J. P. D. Extraction and analysis of lipids. In: AKOH, C. C.; MIN, D. B. (Ed.). Food lipids: chemistry, nutrition, and biotechnology. New York: Marcel Dekker, 1998. Chap. 5.

SOARES JÚNIOR, M. S. Características físicas e valor biológico de rações aquáticas elaboradas em extrusor de dupla rosca com diferentes níveis de substitutos de farelo de soja pela soja integral. Campinas, 2000. 167p. Thesis (Food Technology Doctorate) - Food Engineering College, Campinas State University (UNICAMP).

SWINEHART, J. S. Organic chemistry: an experimental approach. New York: Meredith, 1969.

WHITE, P. J. Conjugated diene, anisidine value, and carbonyl value analyses. In: WARNER, K.; ESKIN, N. A. M. (Ed.). Methods to assess quality and stability of oils and fat-containing foods. Champaign: AOCS, 1995. Chap. 9. 